\title{
Dt 17,14-20: os deveres e direitos do rei
}

Orientador: Leonardo Agostini Fernandes

Mestrando: Rodrigo Ferreira Rodrigues

Área de Concentração: Teologia Bíblica

Linha de Pesquisa: Análise e Interpretação de Textos do Antigo e Novo Testamento

A presente dissertação analisa Dt 17,14-20, a "lei do rei", considerando, de forma especial, elementos diacrônicos examinados à luz dos métodos histórico-críticos. Essa análise provê a base para os tópicos abordados no comentário. O estudo constata que a "lei do rei" exibe certos contrastes e semelhanças em relação a História Deuteronomista, particularmente, os relatos sobre Salomão. A "lei do rei" é, contudo, peculiar em sua forma de avaliar e criticar a tradição. Conclui-se também que os deveres e direitos tratados na "lei do rei" são essencialmente utópicos, apesar de refletir um conhecimento da realidade histórica da qual emergiram. Além disso, constata-se que Dt 17,14-20 demonstra muita similaridade em seus termos e temas com o restante do livro do Deuteronômio e com a tradição bíblica mais ampla, mas também, revela descontinuidade temática. Como base na inter-relação entre a "lei do rei" e outras partes do Antigo Testamento, é possível notar que o livro do Deuteronômio nega ao rei os elementos essenciais ao exercício monárquico no Antigo Oriente Próximo.

Palavras-chave: Torá; "lei do rei"; Pentateuco; Antigo Oriente Próximo; História Deuteronomista. 